\title{
Moving Toward Neo-Totalitarianism: A Political-Sociological Analysis of the Evolution of Administrative Absorption of Society in China
}

\author{
${ }^{1}$ China Institute for Philanthropy and Social Innovation, Renmin University of China, Beijing 100872, China, E-mail: \\ kxg63@vip.sina.com.http://orcid.org/0000-0002-5627-4284.
}

\begin{abstract}
:
China recently promulgated and revised a number of laws, regulations and measures to regulate the nonprofit sector. All these administrative efforts increase support for Chinese nonprofit organizations (NPOs) on the one hand and put unprecedented pressure on them on the other. The seemingly contradictory effects are actually based on the same logic of Administrative Absorption of Society (AAS). This article proposes three phases in the development of AAS: an subconscious phase, a theory-modeling phase, and an institutionalization phase. The institutionalization of AAS has led to the rise of neo-totalitarianism, which is featured by state capitalism, unlimited government, and a mixed ideology of Marxism and Confucianism. Neo-totalitarianism further strengthens AAS and has begun to reshape the relationship between the state and the nonprofit sector. This article analyzes China's nonprofit policymaking from a sociopolitical perspective, and clarifies the context, the characteristics, and the evolution of laws and policies in the nonprofit sector in macrocosm.
\end{abstract}

Keywords: NPO, nonprofit policymaking, administrative absorption of society, neo-totalitarianism, China DOI: $10.1515 / \mathrm{npf}-2017-0026$

\section{The Puzzling Situation}

In recent years, the Chinese government has instituted a series of laws and policies that aim to regulate the nonprofit sector, with one of the most important being The Charity Law of the People's Republic of China (hereafter the Charity Law). This law, promulgated in 2016, facilitates the specification process and enforcement of relevant rules and regulations related to charity in China. It has been accompanied by legal efforts such as the government's increasing support for the Chinese nonprofit organizations (NPOs) through financial and capacity building and various other measures. However, all these administrative efforts, which in theory were established to offer assistance for the nonprofit sector, have in practice put unprecedented pressure on most Chinese NPOs. To understand the misconnections between Chinese laws and the regulation of the nonprofit sector, we need to study the nature and characteristics of the state-society relationship in contemporary China. We also need to look carefully at China's political regime as well as China's emerging and evolving economic order in the Reform Era.

Briefly summarized, the administrative policies adopted by the Chinese government to regulate the nonprofit sector reflect the core institutional mechanism of what I call "Administrative Absorption of Society" or AAS for short (Kang and Han 2007, 118; Kang and Han 2008; Kang, Han, and Lu 2010, 285). In AAS, the government is in a dominant position as governor and supplier of the social order and public services, whereas the NPOs serve the dual purposes of challenging the political authority and providing public services. To make the NPOs work for the governor, the government adopts dual strategies to make full use of the service capacity of the NPOs on the one hand, and to repress their challenging potential on the other hand. It is worth noting that in the theoretical framework of AAS, "society" means "civil society" or "public space." "Absorption" refers to the process through which the government makes a series of efforts to prevent social structures such as civil society or public space from emerging and developing. The gradually emerging "neo-totalitarianism" in the political-economic order of today's China has strengthened the core features of the governance system of AAS. Thus I argue that the empirical puzzle in China's nonprofit sector mentioned above is a direct outcome of the institutional arrangement of AAS under the neo-totalitarian regime.

This article discusses the changing administrative policies for Chinese nonprofit sector from political perspective. First, I examine the institutional background where the governance system of AAS came into being, 
and the structures and functions of AAS. Next, I depict three phases of the evolution of the governance system of AAS, including subconscious origination, theory-modeling, and institutionalization. Following that, I analyze the emerging neo-totalitarianism and how it has shaped the nonprofit sector. In the final section, I conclude with the trajectory of China's neo-totalitarian regime in the future.

\section{The Formation of the Governance System of Administrative Absorption of Society in Regulating Social Organizations}

Since the 1990s, numerous scholars have paid careful attention to the state-society relationship in contemporary China. One widely adopted theoretical perspective is to look at the dynamics of Chinese civil society and predict social change in China. This theoretical tradition has been shaped largely by the scholarly discussions and observations regarding the Tiananmen incident in 1989 and by the radical political transitions that happened in the former Soviet Union and Eastern Europe during the late 1980s and early 1990s. The Chinese academic community has embraced the theories originated in the West, such as the theory of "civil society" (Deng 2002; Gao and Yuan 2008; White 1993; Yu 2000) and corporatism (Chan 1993; Oi 1992; Saich 2001; Unger 1996; Unger and Chan 1995). Acknowledging the gap between the explanatory power of these Western theories and the Chinese experience, China scholars tend to revise the imported theoretical terms. One good example is to use "state-led civil society" (Frolic 1997) to describe the state-society relationship in contemporary China. Given the fact that China is a huge country with many regional distinctions and complexities, it is not a difficult task to discover supporting "empirical evidence" for any theoretical perspective. The researchers may draw biased conclusions from the partial, incomplete evidence they gain in their selected sample. This phenomenon in China studies is similar to what one Chinese idiom says - a group of blind men touching an elephant and learning what it is like only by the parts they touch (Baum and Shevchenko 1999).

I argue that the theory of AAS can offer a systematic framework to depict and explain the state-society relationship in contemporary China. The governance system of AAS took root in the post-totalitarian institutional environment. China's radical economic reform led by Deng Xiaoping has transformed the Chinese society that was installed by Mao's communist regime. The most fundamental change took place first in the economic system was that market mechanisms have gradually replaced the previous centralized planning. The marketoriented reforms have further facilitated social changes; individuals have been given increasing private space and more, albeit insufficient, freedom of speech, assembly and association. Overall, the society has gradually moved away from the government's tight control and become more autonomous. New capitalists and a middle class have emerged and grown. Chinese citizens have improved their living standards and education considerably. Development of information technologies, particularly those related to the Internet, has been impressive. Such domestic transitions and China's opening up to the world happened simultaneously. China has actively embraced the recent economic globalization and has initiated and maintained extensive communication with the international community.

All these changes have led to an important political outcome; that is, China's totalitarian regime ${ }^{1}$ during Mao's era has been replaced by a post-totalitarian regime, ${ }^{2}$ as defined by Linz and Stepan (1996). Despite the lack of substantial democratization in China's political regime, a certain degree of freedom has been evident. As a matter of fact, such a political change is the inevitable byproduct of China's marketization, rather than an outcome deliberately pursued by the Chinese Communist Party (CCP). On the one hand, given all the new changes, the Chinese government cannot eradicate the newly emerging social forces, including capitalists, the middle class, new professionals such as lawyers, social media, universities and intellectuals, and all kinds of social organizations ${ }^{3}$ and the civic movements they sometimes organize. On the other hand, the government has remained intolerant of the continuing growth of such social forces and the resulting potential threat to its political power. The question is, in light of these tensions, how will the government deal with the dilemma it faces?

From the government's perspective, social organizations serve dual purposes. First, as the carriers of collective action, social organizations have the potential to challenge the government's political authority. Second, as the providers of public services, social organizations can complement what the government fails to do in the public sector. The government also has dual functions. The government is the ultimate ruler, monopolizing political power, and it is responsible for offering necessary public services. Thus unavoidable conflicts exist between the authoritarian government and social organizations regarding political resources and power, while at the same time, the possibility exists for cooperation in providing social services. As a rational economic actor, ${ }^{4}$ the government is likely to employ dual strategies: repressing social organizations' potential to threaten the government's political power and simultaneously taking advantage of their function of providing public goods. The government has thus initiated the policy of "graduated control" (Kang and Han 2008); that is, re- 
pressing those social organizations with the most potential to threaten the government's political power and supporting those with the greatest ability to provide public goods. As a result, the government has created a group of social organizations that can offer public goods but lack the potential of challenging the political regime. Moreover, because these social organizations resemble some of the non-governmental organizations (NGOs) in the West, they serve as the replacement for Western NGOs in Chinese society.

\section{The Transformation of the Governance System of Administrative Absorption of Society}

The governance system of AAS evolved from China's post-communist political regime (Linz and Stepan 1996) over the past four decades. This governance system started with informal practices. When the government gained some "consciousness" of such practices, it then facilitated the theorization of such informal practices. Later, a governance system of AAS was institutionalized, during which a set of formal institutions came into being, including the relevant laws, regulations, and policies.

\section{The First Phase of Development (1976-2010)}

The government still lacked a consciousness of the governance system of AAS. During the initial stage of the development of social organizations, the government's regulation in this regard was in disarray, and there was not a specific administrative agency to take charge. In 1989, the government issued the Regulations for Registration and Management of Social Associations to regulate NPOs at that time. This legislation served as the base for the initial administrative system. This nascent system had two core defining features, e. g., its dual management agencies, one for regulating the registration of social organizations and the other for supervising the activities of social organizations. Only Party and government organizations or their designated agencies can serve as the supervisory agencies. Also, it was stipulated that, for the same category of social organizations, only one social organization could be established in one administrative region. Moreover, social organizations were prohibited from building branches.

Although the governance system of AAS emerged, developed its political goals and logic of action, and worked quite effectively during this developmental stage, it was not an outgrowth of governmental action. It is possible that the government was not even aware that such a governance system existed. Numerous government officials and agencies subconsciously employed a wide range of formal and informal strategies on a daily basis to handle their regular affairs and sometimes urgencies or crises. All these practices were accumulated and gradually grew into the system of AAS. This system's key characteristics, such as coherent goals, the rigorous logic of action and the effectiveness of action, reflected the shared interests of government officials as well as the agencies they served. Thus the governance system of AAS was a product of collective action among government officials with some degree of consciousness.

\section{The Second Phase of Development (2010-2013)}

The governance system of AAS was acknowledged in theory, which was characterized by the formation of official policies. The Chinese government made a "new blueprint" for social management (shehui guanli) in 2010 by constituting three key rules. ${ }^{5}$ The new social management pattern is featured by the party's leadership, the government's supervision, social coordination and civic engagement, and that the general public must participate. The promulgation of these rules signified that the ruling party found a competitive institutional replacement for civil society. Thus the government not only deconstructed the Maoist regime and civil society but also became the designer and builder of a new model.

The new blueprint mapped out by the central government kept the essence of the governance system of AAS and advanced this system in almost every aspect. This new blueprint presented conspicuous changes, as compared with the previous system. The new blueprint clearly recognized the importance of social organizations, encouraged social organizations to take part in social management, and provided social organizations with a variety of opportunities and resources as well as new channels for their future development. At the same time, the new blueprint selectively imported some theories and practices to public administration that were developed in the West over the past three decades, such as social coordination and public participation.

However, this new blueprint still kept the essence of China's party-state regime. The ruling party still played the predominant role. The party organization directly managed most affairs of civil administration, by both 
instituting guiding principles and policies and enforcing these policies. The party organization and the government system were in the same boat - the party steered the boat, whereas the government operated it. Such a core operational system was supported by the party's mass line policy, which encouraged the people to get involved. As a result, the new blueprint delineated a party-centered hierarchy in which the party committee, the government, the mass organizations (including grassroots self-governed organizations), state-owned enterprises, social organizations, social workers, volunteers, and the general public were ranked in order as a series of concentric rings. The center of this hierarchical system was the party, which enjoyed absolute political power. The closer an organization was to the center, the more trust it received from the center, the more duties the party assigned to it, and the more power it held. Therefore, this hierarchical civil administration system was under the charge of the ruling party and was operated by the government. Because the party-state needed and valued the public services offered by social organizations, it supported the development of these organizations, especially in areas with the greatest needs. But all issues related to politics were out of the discussion. All types of coordination and participation had to be led by the party. The new blueprint expected to create a society that could offer help, rather than trouble, to the government. In the system delineated by the new blueprint, autonomy, independence, and cohesion were not allowed to exist in the society. The "social" aspect is void in this society, meaning the incomplete nature of a real society. It is clear that repressing the "social" nature of the society was an essential feature shared by the totalitarian regime, the system of AAS, and the system designed by the new blueprint. As a result, the government could maintain its political monopoly by undermining the autonomy and cohesion of the society and stifling the collective action of social forces.

In summary, the fundamental logic of how the government manages its relationship with the society via the AAS governance system remains the same as in the previous totalitarian regime. However, the new system has been improved, and the party-state has become more conscious of how it works.

\section{The Third Phase of Development (2013 - present)}

The governance system of AAS has been institutionalized and legalized. Since the Xi Jinping administration began, the Chinese government's civil administration has developed into a new stage. The Charity Law, a seemingly meaningful legal act, was promulgated in 2016. However, the Charity Law and its follow-up regulation did not make significant improvements over what was delineated in the new blueprint. In this sense, the Charity Law was no more than a publicity stunt.

During this developmental phase, the most consequential change took place in the political arena, and in turn these political changes have had a profound influence in the social space. I regard China's ongoing political changes as "moving toward a neo-totalitarian regime."

\section{Neo-Totalitarianism and How It Affects the Civil Sector}

There have been some clues in the public speeches by the Chinese leaders or in the government's official documents that neo-totalitarianism was emerging. However, no evidence was clearer than what the head of the Central Commission for Discipline Inspection (CCDI), Wang Qishan, said during the National People's Congress (NPC) and the Chinese People's Political Consultative Conference (CPPCC) in 2017:

In Chinese traditional culture, the "government" is understood in an extensive sense and expected to have unlimited responsibilities. The common people must treat the party organizations, the administrative agencies and the judicial organs as the representatives of the government. Under the party's leadership, there exists the division of labor between the party and the government. But the party and the government should not be independent of each other. We must be clear about this principle, keeping our confidence in our socialist system with Chinese characteristics not only in building our theory but cultivating supporting institutions and cultures. Furthermore, the party should strengthen the check of power over its organizations and simultaneously over the government system. The internal supervision of the party organization should cover every government official and facilitates the self-discipline of both party and government agencies (Huanqiu 2017).

Wang delivered a clear message that today's political ideology has denied the "separation of the party and the government" proposed by Deng Xiaoping and returned to Mao's "integration of the government into the party," and the message took a clear-cut stand in strengthening the CCP's centralized political power and its unlimited government. What's more, Xi Jinping delivered a report at the 19th National Congress of the Communist Party of China in October 2017, which claimed to "ensure the party's leadership over all work." On March 11, 2018, 
the NPC passed the amendments to the Constitution of the People's Republic of China. The amendments further strengthened the leadership of the CCP in the Constitution with new provisions that "the leadership of CCP is the ultimate essential feature of socialism with Chinese characteristics." All these speeches and legislative changes are signs that China's political regime is "moving toward neo-totalitarianism."

The past study always regards neo-totalitarianism and post-totalitarianism as the same type of regime, which is different from totalitarianism and authoritarianism (Linz and Stepan 1996). Most researchers view the pre-1989 communist government as neo-totalitarianism or post-totalitarianism (Ghodsee 2008). The postStalin Soviet Union, Czechoslovakia, East Germany and post-Mao China are all good examples (Thompson 2001). However, China's political transformation is a continuous process that is usually seen as starting with the reform in 1978 and continuing after the collapse of Soviet communism in 1989. From different perspectives, researchers summarized the "China Model" initiated by Deng Xiaoping as neo-totalitarianism, ${ }^{6}$ posttotalitarianism ${ }^{7}$ or post-totalitarian capitalist developmental state. ${ }^{8}$ These concepts reach a consensus on neototalitarian features in the "China model" after the 1978 reform, including one-party leadership, socialist market economy or state capitalism, ideological polarization and limited pluralism in nonpolitical areas, and so on.

The structural features of China's neo-totalitarian regime can be summarized as follows. In the economic realm, the neo-totalitarian regime is associated with "state capitalism." In the political realm, this neototalitarian regime perseveres in Leninism, centralized political power, a unified party-state system, and an unchecked government. Ideologically, China's neo-totalitarianism adheres to Marxism and, more importantly, depends on Confucian political cultures as well as nationalism for its political legitimacy. In the social realm, China's neo-totalitarian regime constrains the people's freedom of speech, assembly, and association and regulates social organizations via the governing system of AAS. Finally, China's neo-totalitarianism maintains its foreign policies of opening up and embraces free trade.

To better understand neo-totalitarianism, we can contrast it with liberalism. First, China's neototalitarianism adheres to Marxism ideologically but develops a capitalistic economic system. China's neototalitarianism accepts the economic dogma of liberalism but rejects its political and social doctrines. Thus the ideology of China's neo-totalitarianism is a combination of revised Marxism, China's traditional political philosophy, and nationalism. Second, China's neo-totalitarianism embraces a political dictatorship where the CCP keeps its political system of "one-party, one government, and one leadership," albeit offering a certain degree of political freedom to the general public. In contrast with a liberal one, this neo-totalitarian regime denies the citizens' political rights. Third, China's neo-totalitarianism is associated with a market system with strong characteristics of state capitalism and a highly planned economy, whereas liberalism is coupled with a mature market economy. The social space is buried by the neo-totalitarian regime, whereas liberalism is supported by civil society. Furthermore, China's neo-totalitarian regime develops a governing system of AAS to regulate social organizations. This governance system is not built to eliminate the autonomy of the social realm entirely. In fact, the government aims to take advantage of all kinds of social organizations and gain support from social groups and in particular the social elites, allowing them to complement the government's public service functions. So the government may encourage the development of some types of social organizations and even turn a blind eye to some social elites' behaviors of reaping profits from their organizations, as long as these social organizations set themselves as subordinates to the government. Moreover, the neo-totalitarian regime builds party branches into all the social organizations, exerting ultimate party control over the social field. Thus, in the Chinese social realm, a certain degree of social autonomy and the ruling party's political control coexist.

In the neo-totalitarian regime, the government has taken an aggressive stance in regulating social organizations in a number of ways. On the one hand, the government has adopted many regulatory measures. First, the government extensively builds party branches into all kinds of social organizations. ${ }^{9}$ Second, the government strengthens the functions of the agency in charge of the registration of social organizations and the agency supervising social organizations' routine affairs. Third, the government employs its administrative bureaus of industry, commerce, taxation, and relevant legal bureaus as well as the government's official media to punish social organizations that disobey the government's commands. For example, the administrative bureaus of industry, commerce, and taxation are more likely to investigate the financial and accounting records of social organizations that are placed on the government's blacklist. Once the problems are identified, the government tends to use strict legal means to punish these social organizations. The government also uses its official media to publicize the "illegal" or "ethically inappropriate" behaviors of social organizations or even their "treasonous relations" with foreign governments or international organizations. In the worst scenario, the security agencies will arrest the leaders of the social organizations involved in such activities. In 2015, for instance, leaders of a few social organizations concerned with labor issues were put in jail. Fourth, the government exerts extreme control over the development of foreign NGOs in China, aiming to break the connections between the foreign organizations and local NGOs and weaken foreign influence on Chinese society. In 2016 China enacted the Law of Administration of Activities of Overseas Nongovernmental Organizations in the Mainland of China. The practice of this law was put in the hands of China's security system. ${ }^{10}$ 
On the other hand, the government has employed many supporting policies. First, the government offers social organizations a certain degree of autonomy and respects their "logic of action," demanding less unreasonable intervention by the administrative agencies. Second, the government prohibits incumbent and retired government officials from assuming leadership positions or any positions in the board or directors and board of supervisors in a social organization. Third, the government loosens its control over the social organizations that are obedient and have important social functions, such as charity organizations, community organizations, industry associations and chambers of commerce. Such organizations can be exempt from seeking supervisory agencies. The government is likely to adopt more lenient criteria for their registration. ${ }^{11}$ Moreover, such social organizations can receive preferential or even rewarding contracts from the government. ${ }^{12}$ Fourth, the government develops the incubators in localities that give birth to and cultivate the social organizations that the government needs most. These social organizations are expected to work for the government and complement the government's public service functions.

It is concluded that in China's neo-totalitarian regime, the governance system of AAS for regulating social organizations has been tremendously strengthened. This system considerably constrains social autonomy and stifles the democratization progress. It also prevents the relatively recent "color revolutions" that have occurred in many regions of the world from happening in China. This system delineates a clear boundary for the freedom enjoyed by the social organizations and weakens the potential influence of international forces, including the international NGOs, on China's political realm. Furthermore, governed by the system of AAS, China's social organizations have been guided to focus primarily on developing their functions of providing social services and have gradually lost their capacity to challenge political authority. Overall, China's social realm, which consists of "eunuch-like" social organizations, has become one of the government's tools for regulating the society.

\section{The Future of Neo-Totalitarianism}

The deepest root of today's neo-totalitarianism can be traced back to Maoist totalitarianism. Deng's economic reform did not eradicate it. Other factors accounting for the recent rise of neo-totalitarianism include the "political genes" of $\mathrm{Xi}$ and his new administration and the CCP's regained confidence in its ruling power, which is strengthened by China's four-decade economic growth. The tough means adopted by other emerging economies, such as those in Russia and India, to handle the international NGOs also inspired the Chinese leadership to embrace neo-totalitarianism.

However, it is worth noting that there are some long-standing, persistent factors in Chinese society that are likely to accelerate the decay of Marxist ideology and cause a legitimacy crisis for neo-totalitarianism. One factor is continuing growth of Chinese citizens' civic consciousness and self-organizing capacities as well as social autonomy. The worldwide Internet revolution in recent decades has considerably strengthened the general public's abilities to act and has simultaneously hamstrung the government's political control. Moreover, pressure from the international community and particularly the international NGOs' "demonstration effect" also helps to shape the state-society equation in China. Finally, some inherent problems within the neo-totalitarian regime may erode the regime's sustainability.

The growth of China's social autonomy in the future depends on the further maturation of market mechanisms, the expansion of the middle class, the rationalization of governmental actions, and the interactions between China and the rest of the world. Two fundamental factors also matter in this regard. The first factor is the cultivation of public spirit and cultural values among Chinese citizens. The second is a political factor, which is the demand for the enforcement of individuals' constitutional rights and, in particular, the rights for freedom of speech, assembly, and association. China's political future entails a search for solutions to two significant issues: how to cultivate viable public spirit in the Chinese society and how to guarantee and safeguard Chinese citizens' civic rights.

\section{Acknowledgments}

The author wishes to thank Beijing Yifang Foundation for its financial support.

\section{Notes}


1 Friedrich and Brzezinski summarize six basic characteristics of a totalitarian regime. The first is a fragile official ideology that covers all aspects of society and that demands that all members of society embrace it. This ideology denies the legitimacy of all previous value systems and promises to build a brand-new and perfect society. Second, a totalitarian regime has a single party, often led by only one core leader. This party is guided by the above-mentioned official ideology and has a tightly organized governmental bureaucracy with a clear, stratified ranking system. Third, this regime has a terroristic police system that embraces modern technologies and regulates the society. Fourth, this regime has a communications monopoly that absolutely controls mass media. Fifth, a totalitarian regime enjoys a weapons monopoly. Finally, within this regime, the central government controls and directs the economy and other social organizations (Mayer, Burnett, and Ogden 1996, 219).

2 According to Linz and Stepan, post-totalitarianism features constrained leadership and increasing technocrats, superficial ideology and declining common beliefs, ritualized and unenthusiastic regime mobilization, and limited pluralism in nonpolitical areas, and so on (pp. 42-51). Post-totalitarianism stems partially from Stalinism, but is mainly from social reforms in the communist countries. A post-totalitarian regime roots out the cruelest repression mechanism in its political control machine but maintains most of the other control measures ( $\mathrm{p}$. 50). Also, a post-totalitarian regime can contain some transitional, dynamic systems such as the transition from a nascent post-totalitarian regime to a static one and to a mature one. A nascent post-totalitarian regime is close to an ideal type of post-totalitarianism, but in this nascent system, the leadership's power is not unlimited. In a static post-totalitarian regime, almost all the control mechanisms adopted by the party-state can exist for a long time, although the regime seems generous toward criticisms from civil society. In a mature posttotalitarian regime, the party keeps its inviolable political leadership, whereas changes take place in most of other aspects regarding the regime (p. 42). They also stress that, in contrast with a post-totalitarian regime, an authoritarian regime is associated with more diverse social and economic elements. In particular, an authoritarian regime often has a private sector with more autonomy and allows for more religious freedom and more open cultural products (p. 43).

3 In today's China, NPOs are called "social organizations," which comprise social associations (shehui tuanti), social service organizations (shehui fuwu jigou), and foundations (jijinhui). See Wang and Wang (2018) for a discussion of NPOs and social organizations.

4 The theory of Administrative Absorption of Society assumes that the government is a rational economic actor that will maximize its interests and seek the best match between its goals and means.

5 These three key documents include Outline of the 12th Five-Year Plan for the National Economic and Social Development of the People's Republic of China, Hu Jintao's speech at the provincial-and ministerial-level seminar on social management and innovation delivered to major cadres in 2011, and Zhou Yongkang's speech of "Strengthening and Innovating Social Management: Building the Socialist Social Management System with Chinese Characteristics."

6 The era opened by Deng Xiaoping is characterized by socialist market economy or state capitalism, elite alliance under the leadership of $\mathrm{CCP}$, authoritarian regime, AAS, absolute development orientation, nationalism, and government-led pluralist model or authoritative integration (Kang 2014; Kang and Xu 2013).

7 The economic reform in contemporary China has led to a post-totalitarian system. The system is featured by social mobilization capacity under one-party leadership, limited pluralism in nonpolitical areas and expansion of free space, secular ideologies and division of interest groups, and so on (Xiao 2008).

8 Since the second-generation leader Deng Xiaoping initiated the economic reform, mainland China has taken a mixed developmental way with both the post-totalitarian ruling mechanism and the economic model of capitalist developing countries. This combination contributes to a post-totalitarian capitalist developmental state (Wu 2007).

9 The Ministry of Civil Affairs released a document entitled "The Interim Opinions on Strengthening the Construction Work of the Social Organization" September 28, 2015, proposing to establish party branches in all NPOs.

10 According to the law, the Ministry of Public Security and its provincial branches are responsible for foreign NPOs' registration in China. 11 According to the Opinions on Reforming the Management System of Social Organizations to Promote the Healthy and Orderly Development of Social Organizations enacted August 21, 2016, social organizations in urban and rural communities would receive fewer registration restrictions and more encouragement.

12 According to the "Comments on Deepening the Reform of the Social Governance System in Beijing" released August 28, 2015, NPOs should play a bigger role in providing public services. The government should help to improve NPOs' specialization and purchase basic services from them as much as possible.

\section{References}

Baum, R., and A. Shevchenko. 1999. “The 'State of the State'." In The Paradox of China's Post-Mao Reforms, edited by M. Coldman and R. MacFarquhar, 333-334. Cambridge, MA: Harvard University Press.

Chan, A. 1993. "Revolution or Corporatism? Workers and Trade Unions in Post-Mao China." Australian Journal ofChinese Affairs 29: 31-61.

Deng, Z. 2002. Theoretical Study of Civil Society [Shimin Shehui Lilun De Yanjiu]. Beijing, China: China University of Political Science and Law Press.

Frolic, B. M. 1997. "State-Led Civil Society." In Civil Society in China, edited by T. Brook and B.M. Frolic, 46-67. Armonk, NY: M. E. Sharpe.

Gao, B., and R. Yuan. 2008. "Moving to Civil Society." In Blue Book on Civil Society Development in China [Zhongguo Gongmin Shehui Fazhan Lanpishu], edited by B. Gao and R. Yuan. Beijing, China: Peking University Press.

Chodsee, K. 2008. “Left Wing, Right Wing, Everything: Xenophobia, Neo-Totalitarianism, and Populist Politics in Bulgaria." Problems of PostCommunism 55 (3): 26-39.

Huanqiu. 2017. "Some Comments on What Wang Qishan Said during the Two Sessions." Accessed March 7, 2017. http://china.huanqiu.com/article/2017-03/10265099.html.

Kang, X. 2014. Deng Xiaoping and the Transformation ofChina [Dengxiaoping Shidai]. Singapore: World Scientific Publishing Co. Pte. Ltd.

Kang, X., and H. Han. 2007. “Administrative Absorption of Society: A Further Probe into the State-Society Relationship in Chinese Mainland." Social Sciences in China 8 (2): 116-128.

Kang, X., and H. Han. 2008. “Graduated Controls: The State-Society Relationship in Contemporary China.” Modern China 34 (1): 36-55.

Kang, X., H. Han, and X. Lu. 2010. The Governance System of Administrative Absorption of Society: Study of State-Society Relationships in Contemporary China [Xingzheng Xina Shehui: Dangdai Zhongguo Dalu Guojia Yu Shehui Guanxi Yanjiu]. Singapore: World Scientific Publishing Co. Pte. Ltd. 
Kang, X., and W. Xu. 2013. Pluralism and Integration: Empirical Research on Chinese Development Model since the Reform and Opening-Up [Duoyuan Yu Zhenghe: Gaige Kaifang Shidai Zhongguo Fazhan Fangshi Shizheng Yanjiu]. Beijing, China: Social Science Academics Press.

Linz, J. J., and A. Stepan. 1996. Problems of Democratic Transition and Consolidation: Southern Europe, South America, and Post-Communist Europe. Baltimore, MD: Johns Hopkins University Press.

Mayer, L. C., J. H. Burnett, and S. Ogden. 1996. Comparative Politics: Nations and Theories in a Changing World, 2nd ed. Upper Saddle River, N] Prentice Hall.

Oi, J. C. 1992. "Fiscal Reform and the Economic Foundations of Local State Corporatism in China." World Politics 45 (1): 99-126.

Saich, T. 2001. Covernance and Politics of China. Basingstoke, UK: Palgrave Macmillan.

Thompson, M. R. 2001. “To Shoot or Not to Shoot: Posttotalitarianism in China and Eastern Europe." Comparative Politics 34 (1): $63-83$.

Unger, J. 1996. "Bridges: Private Business, the Chinese Covernment and the Rise of New Associations." The China Quarterly 147: 795-819.

Unger, J, and A. Chan. 1995. "China, Corporatism, and the East Asian Model." Australian Journal of Chinese Affairs 33: 29-53.

Wang, J., and Q. Wang. 2018. "Social Autonomy and Political Integration: Two Policy Approaches to the Government-Nonprofit Relationship since the 18th National Congress of the Communist Party of China." Nonprofit Policy Forum 9 (1).

White, G. 1993. "Prospects for Civil Society in China: A Case Study of Xiaoshan City." Australian Journal of Chinese Affairs 29: 63-87.

Wu, Y. 2007. "Macro China: A Post-Totalitarian Capitalist Developmental Country-The Combination of Russo-East-European and East Asia Model." In Metamorphosis of the Party-State: The Elite and Policy of the Chinese Communist Party [Dangguo Tuibian: Zhonggong Zhengquan De Jingying Yu Zhengce], edited by S. Xu and Y. Wu, 309-335. Taipei, Taiwan: Wu-Nan Book Company Ltd.

Xiao, C. 2008. Creat Transformation: On China's Reform from the View of Development Politics [Zhongguo De Dazhuanxing: Cong Fazhan Zhengzhixue Kan Zhongguo Biange]. Beijing, China: New Star Press.

Yu, K. 2000. "The Rise of Chinese Civil Society and the Transformation of Covernance." In Covernance and Good Covernance [Zhili Yu Shanzhi], edited by K. Yu, 326-350. Beijing, China: Social Science Academics Press. 